\title{
Mannheimia haemolytica pleuropneumonia in goats associated with shipping stress
}

\author{
Paula Augusto Taunde ${ }^{1}$ iD Fernando Froner Argenta ${ }^{1}$ Ronaldo Michel Bianchi $^{1}$ iD \\ Bianca Santana de Cecco $^{1}$ iD Andréia Vielmo ${ }^{1}$ Bruna Corrêa Lopes $^{1}$ Franciele Maboni Siqueira $^{2}$ i \\ Caroline Pinto de Andrade ${ }^{1}$ Gustavo Geraldo Medina Snel ${ }^{1}$ Claudio Severo Lombardo de Barros ${ }^{1}$ \\ Luciana Sonne ${ }^{1}$ Saulo Petinatti Pavarini ${ }^{1}$ (iD David Driemeier ${ }^{*}$ (iD)
}

\footnotetext{
${ }^{1}$ Setor de Patologia Veterinária, Universidade Federal do Rio Grande do Sul (UFRGS), 91540.000, Porto Alegre, RS, Brasil. E-mail: davetpatufrgs.br. ${ }^{*}$ Corresponding author.

${ }^{2}$ Laboratório de Bacteriologia Veterinária, Universidade Federal do Rio Grande do Sul (UFRGS), Porto Alegre, RS, Brasil.
}

\begin{abstract}
This study described the epidemiological, clinical, pathological and bacteriological aspects of Mannheimia haemolytica pleuropneumonia in goats associated with shipping stress. Forty goats transported from the Northeast to the Southern region of Brazil died during shipment, or 2-3 days after unloading. Clinical signs included dyspnea, mucopurulent nasal discharge, and coughing. All goats were necropsied, and multiple tissues were collected for histopathological analysis and involved agent identifications. All lungs showed pulmonary consolidation, predominantly affecting the cranioventral lobes, in addition to the marked fibrinous pleuritis, pleural thickening, and pleural adhesions, that affected $90 \%$ of the goats. Histologically, there was fibrino-suppurative pleuropneumonia characterized by a diffuse neutrophilic infiltrate admixed with fibrin. Non-hemolytic [85\% (34/40)] and hemolytic [15\% (6/40)] species were obtained in bacteriological culture. Fir Mannheimia spp. was reported in 26 isolates and subsequently confirmed as M. haemolytica (99\% identity), after amplification and partial sequencing of the $16 S$ rDNA gene. Stress may trigger the development of bacterial pleuropneumonia in goats, and non-hemolytic strains of M. haemolytica may cause this condition in goats with severe immunosuppression.
\end{abstract}

Key words: goat diseases, respiratory diseases, pathology, PCR.

Pleuropneumonia por Mannheimia haemolytica em caprinos associada ao estresse de transporte

RESUMO: Descreve-se os aspectos epidemiológicos, clínicos, patológicos e bacteriológicos da pleuropneumonia por Mannheimia haemolytica em caprinos, após transporte prolongado. Quarenta caprinos transportados da região Nordeste para a região Sul do Brasil morreram durante a viagem ou 2-3 dias após o desembarque. Clinicamente, observou-se dispneia, secreção nasal mucopurulenta e tosse. Na necropsia foram coletados múltiplos fragmentos de órgãos para análises histopatológicas e identificação do agente envolvido. Todos os pulmões apresentaram consolidação pulmonar predominantemente em região cranioventral, associada à deposição acentuada de fibrina, espessamento e aderência pleurais em $90 \%$ dos casos. Histologicamente, havia pleuropneumonia fibrinossupurativa caracterizada por infiltrado neutrofilico difuso associado à fibrina. Colônias não hemoliticas [85\% (34/40)] e hemoliticas [15\% (6/40)] foram obtidas pelo isolamento bacteriológico. Mannheimia spp. foi isolada em 26 amostras, os quais posteriormente foram confirmados como Mannheimia haemolytica (99\% de identidade), pela amplificação e sequenciamento parcial do gene $16 \mathrm{~S} r \mathrm{DNA}$. O estresse pode favorecer o desenvolvimento de pleuropneumonia bacteriana em caprinos, e cepas não hemolíticas de M. haemolytica podem causar doença em animais com imunodepressão acentuada.

Palavras-chave: doenças de caprinos, doenças respiratórias, patologia, PCR.

\section{INTRODUCTION}

Respiratory infections are significant causes of death in goats and result a variety of factors, including viruses, bacteria, fungi, parasites, environmental conditions, farming, and host characteristics (MAHU et al., 2015 PONNUSAMY et al., 2017). Bacteria are the main infectious agents in goats with respiratory disease. $M$. haemolytica is an opportunistic bacterium that causes pleuropneumonia in ruminants, mainly cattle, and although, goats are less susceptible they are also vulnerable in stressful conditions such as transportation (RAHAL et al., 2014; PONNUSAMY et al., 2017; SINGH et al., 2011).

M. haemolytica pleuropneumonia can affect goats of all ages (RAHAL et al., 2014; EKONG et al., 2015). The disease can cause high economic losses due to treatment costs, slowdown in weight gain, condemnation of carcasses, and a decrease of meat and milk production (EMIKPE et al., 2010; PONNUSAMY et al., 2017). Diagnosis is based on clinical history, clinical signs, gross and histopathological findings, associated with bacteria 
isolation, and confirmation by molecular techniques (AHMED et al., 2017; EKONG et al., 2015; PONNUSAMY et al., 2017; RICE et al., 2008).

Treatment consists of antimicrobial drugs such as ampicillin, penicillin, ceftiofur, ceftriaxone, and enrofloxacin (RAHAL et al., 2014). However, prevention strategies are more effective and include the improvement of housing conditions, sanitary management, and biosecurity practices. Avoiding stressful factors, such as the assembly of animals from different origins without proper quarantine is also effective (SILVA et al., 2012; ZECCHINON et al., 2005). Additionally, administration of minerals, vitamins, food, and water of high quality, can aid in prevention (EMIKPE et al., 2010). Many farmers do not understand the effects of poor transport conditions, which often lead to a reduction in immunity and colonization of the lung by opportunistic agents. This report described the epidemiological, clinical, pathological, and bacteriological findings of $40 \mathrm{M}$. haemolytica pleuropneumonia cases associated with stress due to shipment.

\section{MATERIALS AND METHODS}

Epidemiology, clinical signs, pathology, and bacteriology

Over a 1.5-year time span (June 2016 to December 2017), eight trucks transported hundreds of goats along similar routes from the Northeast Brazil to Porto Alegre. These goats were housed in two farms located in the municipality of Porto Alegre (Parallel $30^{\circ}$ between $29^{\circ} 10^{\prime} 30^{\prime \prime}$ South and Meridian $50^{\circ}$ between $51^{\circ} 05^{\prime} 00^{\prime \prime}$ 'West), where 40 goats died and were sent for necropsy. At necropsy, fragments of various organs were collected and fixed in $10 \%$ neutral buffered formalin. Samples were routinely processed and stained with Hematoxylin and Eosin (HE) for histopathological analysis. Samples of lungs were also collected for bacteriological culture. Data on the outbreak was obtained through fieldwork on the farms.

Samples were processed and cultivated under aerobic and microaerobic conditions in $5 \%$ sheep blood agar and MacConkey agar, and incubated for $72 \mathrm{~h}$ at $37^{\circ} \mathrm{C}$. The isolated bacterial colonies were identified by their cultural, morphologic and biochemical characteristics according to MARKEY et al. (2013).

\section{Molecular identification}

Twenty-six bacterial isolates were submitted to polymerase chain reaction (PCR) assay to identification.
Bacterial cells were harvested from blood agar and total bacterial DNA was extracted using QIAmp DNA Kit (Qiagen) according to the manufacturer's instructions. The PCR assay was projected for the amplification of a 499bp fragment of Mannheimia spp. 16S rRNA gene (forward primer: 5'-TCACCAAGCCGTCGATCTCT-3', reverse primer: 5'-TTCGCACATGAGCGTCAGTAC-3). PCRmix included 1U Taq Platinum (Invitrogen), 10X of buffer Taq, $15 \mathrm{pmol}$ of each primer, $200 \mathrm{nM}$ of each deoxynucleotide triphosphate (dNTP), $1.5 \mathrm{mM} \mathrm{MgCl} 2$ and $20 \mathrm{ng}$ of the total DNA in a final volume of $25 \mu \mathrm{L}$. The PCR conditions were: $95^{\circ} \mathrm{C}$ for $5 \mathrm{~min}$ followed by 35 cycles of $95^{\circ} \mathrm{C}$ for 30 seconds (s), $59^{\circ} \mathrm{C}$ for $45 \mathrm{~s}$ and $72^{\circ} \mathrm{C}$ for $30 \mathrm{~s}$, and a final cycle of $72^{\circ} \mathrm{C}$ for $10 \mathrm{~min}$. The Mannheimia specie determination was performed amplifying the whole 16S rRNA ribosomal sequence $(1,450 \mathrm{bp})$ following by sequencing and analysis according previously described by SIQUEIRA et al. (2018). The generated sequence was deposited in the GenBank (accession number MK106144). Multiple alignment were performed with Mannheimia related species $16 \mathrm{~S}$ rDNA sequences, available from GenBank (NCBI) database, in ClustalW alignment, and a phylogenetic tree was constructed using the genetic distance model of Tamura-Nei by UPGMA method with 1,000 replicates, including Escherichia coli as outgroup, in the Genious Tree Builder (Geneious version 9.1).

\section{RESULTS}

In eight shipments of goats conducted from June 2016 to December 2017 from Northeast Brazil to Porto Alegre in closed trucks with poor ventilation and hygiene, 40 6-month-old to 4-yearold goats (28 males and 12 females) died due to pleuropneumonia. All goats were densely crowded together, irrespective of their origin, age, sex or health condition. The mortality levels varied in each transport, and included other causes, such as haemonchosis, cetosis, E. coli, Salmonella spp. and Eimeria spp. enteritis. Each truck carried 300-700 goats and traveled a distance of $3,769 \mathrm{~km}$ over for approximately 5 days. According to the owners, goats were not allowed to leave the truck during the shipment, and water was not available. On arrival, some goats were dead, and others showed symptoms including poor body condition, apathy, anorexia, dyspnea, bilateral mucopurulent nasal discharge (Figure 1A), and died within 3-5 days.

At necropsy, goats had a regular to poor body condition, were dehydrated, and showed mucopurulent nasal discharge. Consistent findings included non-collapsing lungs with varying degrees of right cranioventral consolidation (Table 1). These 


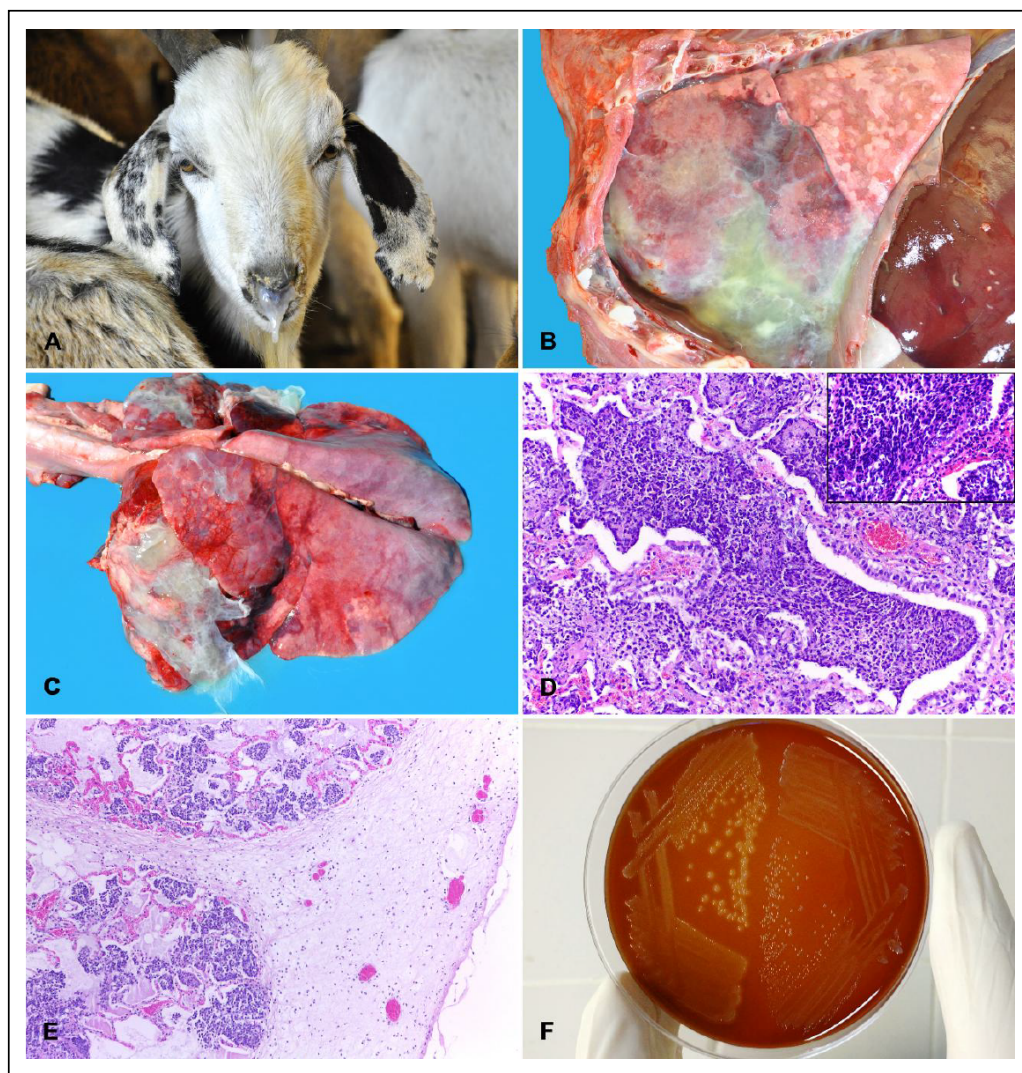

Figure 1 - Pleuropneumonia by Mannheimia haemolytica in goats in Brazil. (A) Bilateral mucopurulent nasal discharge. (B) Lung. Focal area of consolidation in the cranioventral region with marked deposition of fibrin. (C) Bilateral cranioventral lung consolidation with marked deposition of fibrin. The lungs are emaciated and present bright aspect. (D) Lung. Bronchi, bronchioli and alveolar spaces are filled by large amount of neutrophils associated with necrosis of the respiratory epithelium and fibrin deposition. HE, obj. 20x. Inset: neutrophils with elongated nuclei ("oat cells"). HE obj. 40X. (E) Lung. Pleura and interlobular septa are thickened by neutrophils, fibrin and edema. HE, obj. 20x. (F) Blood agar: hemolytic (left) and non-hemolytic (right) colonies of $M$. haemolytica.

consolidation areas were dark-red and firm, and frequently covered by fibrin (Figure 1B and 1C), in addition to a pinkish foam in the trachea and large bronchi. In 90\% (36/40) of the cases, adhesions of the visceral to parietal pleura were observed. Gelatinous pleural effusion occurred in $37.5 \%(15 / 40)$ of the necropsied goats. Twenty percent $(8 / 40)$ of the goats had large numbers of nematodes (Haemonchus contortus) in the abomasal lumen.

Histologically, all goats had a fibrinosuppurative pleuropneumonia, characterized by a marked focally extensive inflammatory infiltrate in the pleura, alveoli, bronchi, and bronchioles.
Exudate consisted mainly of intact and degenerate neutrophils occasionally with deformed elongated nuclei ("oat cells") associated with marked necrosis of the respiratory epithelium and fibrin deposition (Figure 1D). Additionally few lymphocytes, plasma cells, or macrophages were observed within the cellular infiltrate. The visceral pleura was markedly thickened by a layer of fibrin associated with neutrophils (Figure 1E). Marked intra-alveolar and interlobular edema of the pulmonary septa was observed in all cases.

In all samples cultured in blood agar, pure cultures of the genus Mannheimia were isolated, of 
Table 1 - Distribution of lesions in the pulmonary lobes.

\begin{tabular}{lc}
\hline Distribution & Cases (\%) \\
\hline Cranioventral & 67.5 \\
Cranial & 22.5 \\
Multifocal & 2.5 \\
Middle & 2.5 \\
Cranial and middle & 5.0 \\
\hline
\end{tabular}

which $85 \%(34 / 40)$ were non-hemolytic and $15 \%$ (6/40) were hemolytic phenotype. The isolates were positive for esculin-hydrolysis, negative for ONPG beta-galactosidase and unable to grow on MacConkey's agar.

The PCR assay was positive for Mannheimia spp. in all isolates, as identified by the $16 \mathrm{~S}$ ribosomal RNA gene. Subsequently, $M$. haemolytica was confirmed by complete sequencing of the $16 \mathrm{~S}$ rDNA gene with $99 \%$ identity in all analyzed isolates. Furthermore, the phylogenetic analysis (Figure 2) confirmed the bacteria as $M$. haemolytica, by the clusterization of the N706/16 others $M$. haemolytica strains with high confidence.

\section{DISCUSSION}

The diagnosis of pleuropneumonia in the goats of the current report was based on epidemiological, pathological, bacteriological, and molecular findings. The shipment of goats is a common farm practice (SINGH et al., 2011). However, transportation of live animals between distant regions without animal welfare consideration may result in high mortality. Deaths are most often caused by respiratory disease, a condition known as "shipping fever" (VIANA et al., 2007; ROSA et al., 2013). Aggravating adverse conditions in transportation were evident in our study. The goats were transported between two distant and markedly different regions (the Northeast and the Southern Brazilian regions are climatically distinct, especially, regarding temperature and humidity). Transportation vehicles had a closed environment with poor air quality and densely crowded animals. Pneumonia caused by stress due to transportation has been described in shipping fever in cattle (ROSA et al., 2013), sheep, and goats (AHMED et al., 2017; EKONG et al., 2015; RICE et al., 2008).
Gross and microscopic lesions observed in all goats examined in the present study are similar to those described for shipping fever (WILD \& MILLER, 1991; MAHU et al., 2015; ZECCHINON et al., 2005). Aggravating stress factors related to transportation most likely affected the development and severity of the disease observed in the goats of this report; stress factors such as commingling animals from different origins, transmission of the agent among animals, and the maintenance of the infection due to the high humidity, resulted in high morbidity during transport (PONNUSAMY et al., 2017; SINGH et al., 2011). It is likely that the clinical signs were aggravated by the lack of food, and water, the long duration of the shipment, parasitism by bloodsucking nematodes and poor management practices (EKONG et al., 2015; ZECCHINON et al., 2005). It is suggested that all these adverse conditions cause changes in the respiratory microenvironment resulting in upper airway irritation and reduction of mucociliary clearance, reduction in innate immunity, and consequently, adhesion and colonization of the lungs by pathogenic bacteria (RAHAL et al., 2014; VIANA et al., 2007).

M. haemolytica is characterized by hemolysis in blood agar, growth on MacConkey's agar and biochemical positivity and negativity for beta-galactosidase and esculin hydrolysis tests, respectively (MARKEY et al., 2013). However, atypical phenotypic characteristics were reported in $85 \%$ of the isolates of our cases; although, $M$. haemolytica was identified in all samples through the molecular analysis. Using phylogenetic analysis we were able to infer that the isolates are $M$. haemolytica, since other closely related Mannheimia species did not align to our isolates in the phylogenetical analysis.

M. haemolytica with deletion of the hemolysin gene was previously reported in association with pleuropneumonia and septicemia in a bovine calf (MAHU et al., 2015) and in nasopharyngeal biopsy of healthy sheep (WILD \& MILLER, 1991). Non-typical characteristics of the isolates obtained in the present study included no growth in MacConkey agar, as well as beta-hemolytic negative colonies and positive beta-galactosidase ONPG, which is atypical for $M$. haemolytica. It is likely that the immuno compromised goats became more vulnerable to changes from commensal non-hemolytic bacteria to opportunistic pathogens (YENER et al., 2009).

Several factors may interfere in the phenotypic variation of microorganisms, such as environmental factors (RAHAL et al., 2014), enzymatic inhibition by drugs, serotype particularities 


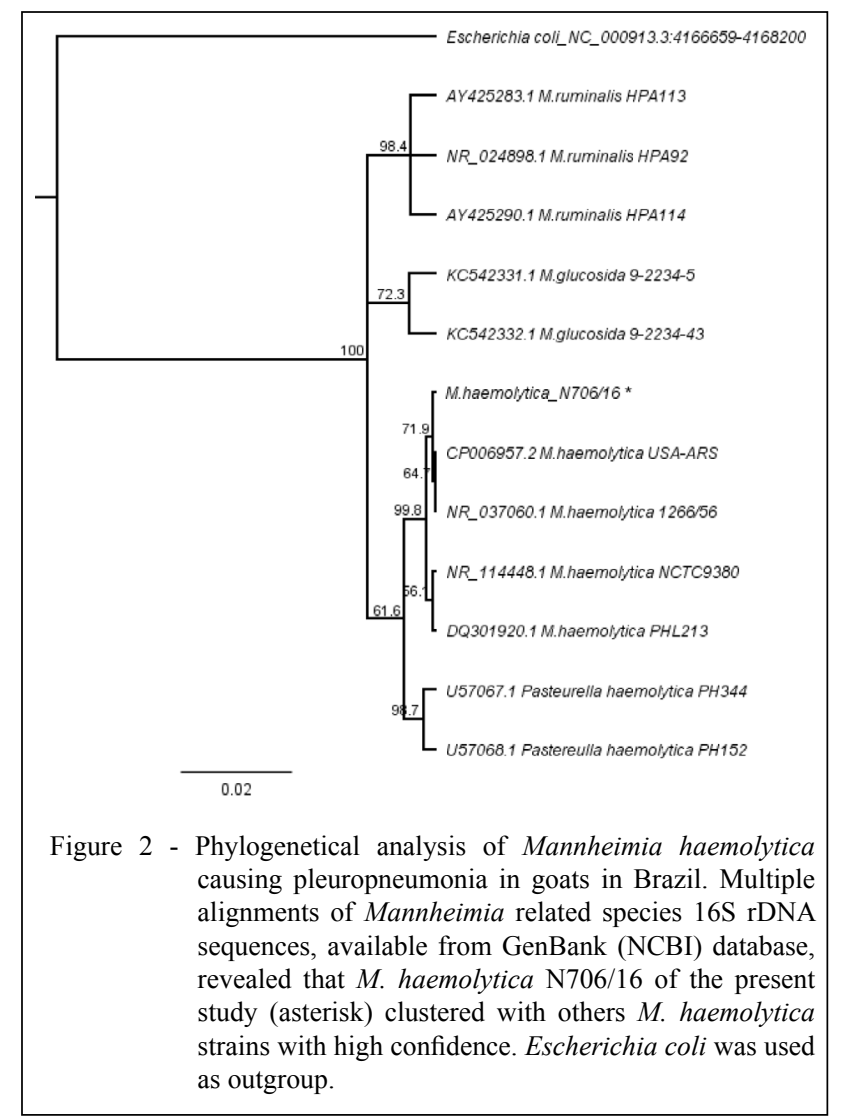

(RICE et al., 2008) and handling of samples (YENER et al., 2009). Other authors have also obtained nonhemolytic M. haemolytica isolates and confirmed them using molecular methods (YENER et al., 2009; MAHU et al., 2015). High sensitivity and specificity of the test were observed in hemolytic as well as non-hemolytic isolates, which makes the molecular test indispensable and recommended for definitive diagnosis of M. haemolytica pneumonia (RAHAL et al., 2014; AHMED et al., 2017).

In conclusion, stressful factors may favor the development of bacterial pleuropneumonia in goats of all ages, and non-hemolytic M. haemolytica colonies can also generate the disease in goats under inadequate welfare conditions.

\section{ACNOWLEDGEMENTS}

We are grateful to the Mozambican Instituto de Bolsas de Estudo (IBE) and to the Brazilian, Conselho Nacional de Desenvolvimento Científico e Tecnólogico (CNPq) and
Coordenação de Aperfeiçoamento de Pessoal de Nível Superior (CAPES), for the support to this work.

\section{DECLARATION INTERESTS}

OF

CONFLICTING

The authors declare no conflict of interest. The founding sponsors had no role in the design of the study; in the collection, analyses, or interpretation of data; in the writing of the manuscript, and in the decision to publish the results.

\section{AUTHORS' CONTRIBUTIONS}

All authors contributed equally for the conception and writing of the manuscript. All authors critically revised the manuscript and approved of the final version.

\section{REFERENCES}

AHMED, W.A.; et al. Molecular and phenotypical characterization of Mannheimia haemolytica. Isolated from goats in Baghdad Province. Advances in Microbiology, v.7, p.304-314, 2017. Available from: $<$ https://www.scirp.org/journal/PaperInformation. 
aspx?PaperID=75840>. Accessed: Nov. 06, 2017. doi: 10.4236/ aim.2017.74025.

EKONG, P.S.; et al. Case report of respiratory mannheimiosis in sheep and goat complicated by Bordetella parapertussis. Nigerian Veterinary Journal, v.35, p.968-974, 2015. Available from: $<$ https://www.ajol.info/index.php/nvj/article/view/112582>. Accessed: Nov. 02, 2017. doi: 10.1016/j.smallrumres.2013.03.007.

EMIKPE, B.O. etal. Experimental infection of Peste des petit ruminant Virus and Mannheimia haemolytica A2 in goats: immunolocalization of Mannheimia haemolytica antigens. Veterinary Research Communications, v.34, p.569-578, 2010. Available from: $<$ https:// www.ncbi.nlm.nih.gov/pubmed/20617380>. Accessed: Nov. 06, 2017. doi: 10.1007/s11259-010-9425-y.

MAHU, M. et al. Non-haemolytic Mannheimia haemolytica as a cause of pleuropneumonia and septicemia in a calf. Veterinary Microbiology, v.180, p.157-160, 2015. Available from: <https:// www.ncbi.nlm.nih.gov/pubmed/26344042>. Accessed: Oct. 26, 2017. doi: 10.1016/j.vetmic.2015.08.019.

MARKEY, B. et al. Clinical Veterinary Microbiology. 2 ed. China: Elsevier Health Science, 2013. 901p. Chap. 21. p. 307-309.

PONNUSAMY, P. et al. Isolation, identification and antibiogram of Mannheimia haemolytica associated with caprine pneumonia in the Cauvery Delta Region of Tamil Nadu. International Journal Current Microbiology Applied Sciences, v.6, p.3118-3122, 2017. Available from: <https://doi.org/10.20546/ijcmas.2017.609.385>. Accessed: Oct. 26, 2018. doi: 10.20546/ijcmas.2017.609.385.

RAHAL, A. et al. Environmental attributes to respiratory diseases of small ruminants. Veterinary Medicine International, ID853627, p.1-10, 2014. Available from: <https://www.hindawi. com/journals/vmi/2014/853627/>. Accessed: Nov. 14, 2017. doi: $10.1155 / 2014 / 853627$.

RICE, J.A. et al. Mannheimia haemolytica and bovine respiratory disease. Animal Health Research Reviews, v.8, p.117128, 2008. Available from: <https://www.ncbi.nlm.nih.gov/ pubmed/18218156>. Accessed: Dec. 03, 2017. doi: 10.1017/ S1466252307001375.

ROSA, F.B. et al. Diseases of goats diagnosed in the Central region of Rio Grande do Sul, Brazil: 114 cases. Pesquisa Veterinária Brasileira, v.33, p.199-204, 2013. Available from: <http://dx.doi.
org/10.1590/S0100-736X2013000200011>. Accessed: Feb. 02, 2018. doi: 10.1590/S0100-736X2013000200011.

SIQUEIRA, F.M. et al. Fibrinous pleuropneumonia caused by Pasteurella multocida associated with bovine lymphoma. Ciência Rural, v.48, p. 1-5, 2018. Available from: <http://dx.doi. org/10.1590/0103-8478cr20170750>. Accessed: Jul. 12, 2018. doi: $10.1590 / 0103-8478 \mathrm{cr} 20170750$.

SILVA, H.W.; et al. Aspects of exploration of dairy goat in Brazil. Revista Brasileira de Agropecuária Sustantável, v. 2, p.121-125, 2012. Available from: < https://doi.org/10.21206/rbas.v2i2.1733>. Accessed: Nov. 06, 2017. doi: 10.21206/rbas.v2i2.173.

SINGH, K.; et al. Mannheimia haemolytica: Bacterial-host interactions in bovine pneumonia. Veterinary Pathology 48(2):338348. The American College of Veterinary Pathologists, v.148, p.338-348, 2011. Available from: <https://www.ncbi.nlm. nih.gov/pubmed/20685916>. Accessed: Dec. 18, 2017. doi: $10.1177 / 0300985810377182$.

VIANA, L. et al. Mannheimia haemolytica and Pasteurella multocida occurrence in healthy and affected lambs. Arquivo Brasileiro de Medicina Veterinária e Zootecnia, v.59, p.15791582. 2007. Available from: <http://dx.doi.org/10.1590/S010209352007000600035>. Accessed: Feb. 02, 2017. doi: 10.1590/ S0102-09352007000600035.

WILD, M.A.; MILLER, M.W. Detecting nonhemolytic Pasteurella haemolytica infections in healthy rocky mountain Bighorn sheep (Ovis canadensis canadensis): influences of sample site and handling. Journal of Wildlife Diseases, v. 27, p.53-60, 1991. Available from: $<$ http://www.bioone.org/doi/abs/10.7589/0090-3558-27.1.53>. Accessed: Jan. 27, 2018. doi: 10.7589/0090-3558-27.1.53.

YENER, Z. et al. Immunohistochemical detection of Mannheimia (Pasteurella haemolytica) antigens in goats with natural pneumonia. Veterinary Research Communications, v.3, p.305-313, 2009. Available from: <https://www.ncbi.nlm.nih. gov/pubmed/18972219>. Accessed: Dec. 05, 2017. doi: 10.1007/ s11259-008-9178-z.

ZECCHINON, L.; et al. How Mannheimia haemolytica defeats host defence through a kiss of death mechanism. Veterinary Research, v.36, p.133-156, 2005. Available from: <https://www. ncbi.nlm.nih.gov/pubmed/15720968>. Accessed: Nov. 06, 2017. doi: 10.1051/vetres:2004065. 